\title{
Nogle navne fra Flensborg bymark
}

Af professor, dr. phil. Kr. Hald.

Til Flensborg bys mark har der varet og er der tildels endnu knyttet et stort antal navne på agerstykker og andre lokaliteter. Takket være det rige flensborgske kildemateriale er det muligt at følge nogle af disse navnes skæbne gennem lange tidsrum, i enkelte tilfælde, hvor navnene er næunt allerede i stadsretten, fra tiden omkring 1300 til nutiden. Allerede derved frembyder disse navne en særlig interesse, idet marknavne som regel først optræder i sene kilder.

Dertil kommer, at adskillige af bymarkens navne belyser del danske sprogs skæbne og udvikling efter middelalderens slutning, og vort kendskab til danskens historie $i$ Flensborg $i$ nyere tid er så ringe, at ethvert, selv nok så beskedent, bidrag hertil vil være of interesse.

I det følgende skal nogle af navnene, og særlig sådanne der har betydning for sproghistorien, omtales nærmere. Det ville være umuligt her at behandle alle flensborgske navne; det drejer sig om flere hundrede ialt. ${ }^{1}$

Bjaverkar (Jordeb. 1594 Beuerkahr; 1720 Flensb. byark. nr. 165 Bjauerkeer; Feldbuch 1738 byark. Biauerkiehr). - Ved Mølledammen i skellet mellem St. Johannes og St. Nikolai mark. Navnet hører sikkert til de allerældste i Flensborg, ja er utvivlsomt ældre end selve bynavnet, idet det er sammensat med ordet bæver, gammeldansk biauær. De yngste fund af bæver i Danmark dateres til bronzealderen, og selv om dyret efter stednavnenes vidnesbyrd må antages at have levet her også $i$ oldtidens senere afsnit, må de relativt få navne på Bæver- være særdeles gamle. Hermed stemmer det godt, at Bjæverskov på Sjælland optræder som herredsnavn (12. årh. Byaversoog). Et andet sjællandsk Bjæverskov er bevaret som navn på en udlod i Ulstrup, Terslev 
sogn.' I Nordslesvig er fire marknavne sammensat med bæver: Bjæverholm, Bjavereng, Bjavermose og Bjavkær (se registret $\mathbf{i}$ Sønderjyske Stednavne); to af dem, Bjavermose og Bjavkær, ligger henholdsvis i Hørup sogn, Als, og Bjolderup sogn, Åbenrå amt, altså ikke langt fra Flensborg. Skrivemåderne viser, at ordet $i$ den danske dialekt i Flensborg har bevaret den gammeldanske diftong ia i den oprindelige form ligesom i størstedelen af Nordslesvig. Det er karakteristisk for de sønderjyske dialekter, at jo længere man kommer mod syd, jo flere eksempler er der på, at denne diftong (den såkaldte brydningsdiftong) er bevaret uden at deltage $i$ den fra rigsmålet kendte overgang til jæ (je) (jfr. sydslesvigsk (H) jalm overfor det nordslesvigske marknavn Hjelm).

Galgemaj (Jordeb. 1594 Gallemaye; tilføjelse stds. 1633 Galliemaye; kort 1768 Galmey). - I Ramsherred. Ved Galgebjerg (Rodeboeck 1594 ahn dem galgenbarge); om byens rettersted på forskellige tidspunkter se Chr. Voigt i Flensburg, ein Heimatbuch I 56. Sidste led i navnet er ordet made "eng «, gammeldansk math. Det gammeldanske th ("blødt $d "$ ) er som $i$ andre sønderjyske dialekter gået over til $\mathbf{j}$.

Hakshøj. (Stadbok 1601 Hackshue; kort 1768 Hacks hoy; Feldbuch 1774 Haxhüe-Theil). - Navn på en tidligere bronzealderhøj ved Johanneskirke, der i 1726 blev sløjfet af bageren Lorenz Moritzen: ved denne lejlighed blev der ifl. Rivesell fundet sausser verschiedenen Urnen auch ein langer Spies von Erz und ein Degengefäss von feinem Golde ". Første led er snarest, som i mange andre navne på -høj, genitiv af et personnavn, muligvis et gammeldansk Hak (k), en stærktbøjet sideform til det fra Sønderjylland kendte Hakki, der antages at indgå i landsbynavnet Haksted.' I Efterleddet -høj, gammeldansk -høgh, er den sidste konsonant svundet, og det lange $ø$ gået over til $\mathbf{y}$, sådan som det er tilfældet $\mathrm{i}$ næsten alle sønderjyske dialekter.

Kobberbjerg (Stadbok 1601 Kopperberch, Kobberbergh; SH 302B i Universitetsbibl. Kiel Kufferbach; kort 1768 Kopper Berg). - I St. Johannes sogn øst for Malledammen ved Kobberlyk (1636 byark. in der Kopper Lïcken, katastret Kupferlücke). Første led synes, ligesom $i$ en række nordslesvigske navne med samme forled, at være ordet kobber, gammeldansk kopar, selv om anledningen til navnene ikke længere er kendt. Måske er det 
bevoksningens farve, der har været navngivende; om et svensk Kopparberget oplyses, at det har navn efter »en delvis rostfärgad bergvägg ". "Skrivemåden i SH 302 turde vise, at gammeldansk p i Flensborgdialekten er gået over til f. Denne overgang har fundet sted såvel i udlyd som mellem to vokaler i de sønderjyske dialekter syd for linien Åbenrå-Tønder. ${ }^{.}$

Morbak (1284 stadsretten latinsk tekst $\S 15$ (afskr. 16. årh) Mordbecke; c. 1300 stadsretten dansk tekst $\S 25$ Marthbæk; 1431 stadsretten nedertysk tekst $\S 24$ (afskr. 1492) Morbeke; jordeb. 1594 Mohrbecke; 1754 byark. nr. 452 Muesbeckdam; kort 1768 Morbeck; kort 1779 Musbeck, Mohrbecke (på kortet to lokaliteter, der støder op til hinanden); katastret Moorbach; moderne optegnelse [musbæk]). - Bæk på grænsen til Klusris, hvorfra den danske udtale er optegnet som [må:bæk]. Ved navnets tolkning må man gå ud fra skrivemåden i den danske stadsret, der viser, at navnet er af samme oprindelse som landsbynavnet Mårbæk i Bedsted sogn, Abenrå amt (1505 Mordbech, Sønderjy. Stedn. IV 27). Rent formelt er der to muligheder for at forklare forleddet. Det kan være et gammeldansk "marth, samme ord som gammelsvensk mardh "skov", der antages at indgå $i$ andre danske stednavne, eller også dyrenavnet mår, gammeldansk marth. Sagligt synes den første mulighed at måtte foretrækkes; det er lidet sandsynligt, at dyrenavnet skulle indgå $i$ to sønderjyske navne på -bæk, da måren ikke har nogen særlig tilknytning til vandet. De yngre kilders Mor(d) - stemmer med formen c. 1300. De er udtryk for den danske forlængelse og runding af a foran rth-forbindelsen og for svind af th $i$ denne forbindelse (jfr. udviklingen af dyrenavnet). Ved denne udvikling falder forleddet imidlertid sammen med og forstås som tysk Moor "Mose «, og der sker da i det 18. årh. det, at man soversætter * navnet til dansk, og den nye, danske form Mosebæk holder sig ved siden af den formentlig tyske, men i virkeligheden oprindelige danske, til nutiden. Forholdet må være et vidnesbyrd om, at der $\mathrm{i}$ det 18 . årh. var en dansktalende befolkning i byen. - Den nye form har en særlig sproghistorisk interesse. Ordet mose optræder her ikke i den nordslesvigske form med langt o (som i dansk rigsmål), men i en form, der forudsætter den fra de sydslesvigske dialekter kendte diftongering af langt (eller som i dette tilfælde tidligt forlænget) o til ue." 
Nedermaj. (1752 byark. nr. 438 Nieder May). - Ved Munketoft. Om formen maj se ovfr. under Galgemaj.

Plankemaj (1682 Schuldprotokoll nr. 362 planckemay; 1697 Marien Schuldprotokoll Blanckermey; 1742 byark. nr. 100 Blankermey; kort 1779 Blancker May; Hebungsregister 1802 Planckemey; kort 1833-34 Blanker May). - På den nuvarende hovedbanegårds plads, men navnet er bevaret som gadenavn. Muligvis efter byens gamle "plankeværk «; se beskrivelsen af dette i politianordningen 1558 (Dipl. Flensb. II 834 ff.). Et dokument fra 1727 (byark. nr. 171) oplyser, at Plankemaj »anfänglich durch die Unreinigkeit bemelten Hafens erwachsen nachher aber mit einem Bollwerck besetzet «. De mange ældre skrivemåder med b kunne dog tyde på, at første led er adjektivet blank eller en gammel sammensætning med dette ord. Blank er forste led i nordslesvigske navne som Blankeng, Blanksig m. fl. Om maj se under Galgemaj ovfr.

Ryde (1398 Dipl. Flensb. I 143 dat holt gheheten de Rude byleghen an dat zuden by Flensborg). - Skov syd for byen, som grev Gerhard skøder til Flensborg i 1398. Navnet er identisk med ordet ryde, gammeldansk rythi, der stadig lever $i$ jyske dialekter i betydningen et blødt moradsigt engdrag med risbuske; en samling unge træer, opløb i en skov; småt egekrat o. lign. \& (Feilberg). Det er almindeligt i sønderjyske stednavne, hvor det, i alt fald som regel, har betydningen $\$$ krat «, ikke den oprindelige betydning "rydning *. Efter skoven har Rødegade (tysk Rote Strasse) og Rødeport (tysk Rotes Tor) fået navn. Eldre former af disse navne er bl. a.: Schötebock 1514 inn de Rude straten; Nikolai kirkeregnskab 1518 in der rüde strate; Schötebock 1549 in der rude stratenn; Schötebock 1563 jn der rode straten; Schötebock 1575 jn de Rodenstrate; Jordeb. 1594 Rodenstraten; Kaufregister 1598 ihn der Roden Straten; 1628 Schoetebock nr. 364 in der rohte Gasse; Ausgabebuch c. 1650 der Rueden strasse. - Jordeb. c. 1436 Dipl. Flensb. I 441 negest der Rudeporten; Schötebock 1568 negst der Rode pforten; Jordeb. 1594 Rödendohre, Rodendohre; Flensb. amtsregnsk. 1595 by der Rude Porten. Det ses af disse former, at det oprindelige forled i det 16 . årh. begynder at afløses af adjektivet rød, tysk rot, en form, der hurtigt bliver den sejrende. Grunden til denne omdannelse er ikke vanskelig at forstå. Ordet 
rød må i den danske dialekt have været udtalt rye med diftongering af det lange $ø$ som i de nyere sydslesvigske dialekter, ${ }^{8}$ og efter at den oprindelige betydning af forleddet er glemt, måske efter skovens forsvinden, har dette så kunnet opfattes som adjektivet.

Snabe (Stadbok 1601 de Schnabe; kort 1779 die Snaff). - Ved grænsen til Harreslev og delvis i denne by. Samme ord som ældre nydansk snabe shørne*, jysk dial. snabe sen strimmel skov, der strækker sig ind i marken " (Molbechs Dial.-Lex.). Det indgår ofte i stednavne $i$ den oprindelige betydning kile, fremspring ${ }^{8}$ og forudsætter et gammeldansk snapi (jfr. Schnaap ved Eckernförde, 1339 Snape). Formen Snaff er udtryk for den sønderjyske overgang af oprindeligt $p$ til $f$; se ovfr. under Kobberbjerg: med $f$ udtales navnet i Harreslev.

Uglebjerg (Feldbuch 1708 Ockelberg; Marien Schuldprotokoll 1720 Uggelberg; Feldbuch 1771 Ogelberg). - Navnet, der også forekommer i Nordslesvig, er sammensat af fuglenavnet ugle, og nogle af formerne gengiver den jyske udtale med o af dette ord (Feilberg).

Vanrad (Schuldprotokoll 1685 Wanderat; 1687 (afskr.) byark. nr. 205 Wanray; kort 1768 Wanraey; katastret Wanrei). - Vanrad er et meget almindeligt marknavn både i Nord- og Sydslesvig, medens det ikke synes at forekomme i det øvrige danske område. Det forudsætter vistnok et gammeldansk wandràth, nært beslægtet med oldnordisk vandrædi ${ }^{10}$ s vanskelighed, ulempe og betegner s noget, som er vanskeligt at råde med ", s jord, som er vanskelig at dyrke». Det er ofte navn på ringe eller afsides liggende lokaliteter. Formerne viser den sønderjyske overgang af gammeldansk th til $\mathbf{j}$.

Vestenvad (1284 stadsretten latinsk tekst $§ 15$ (16. årh.) Wittstugwadt, c. 1300 stadsretten dansk tekst $\S 25$ Withstagwath; stadsretten nedertysk tekst $\S 24$ (afskr. 1492) Westenwayg; Stadbok 1558 datt Wester watt, Westen watt; Stadbok 1601 Westenwath; kort 1765 wester wat; katastret Westenwatt). Bæk, oprindelig vadested, syd for byen på grænsen til Lille Volstrup. Ved navnets tolkning må man ligesom ved Morbæk gå ud fra formen i den danske stadsret. Det ses af kilderne, at det ældre Withstag- allerede i det 15. årh. er blevet sammentrukket til Veste- 
og derefter folkeetymologisk omdannet til Vesten- s vest for «. Uden den ældre, middelalderlige form ville det $\mathrm{i}$ dette tilfælde være umuligt at nå til den rette forståelse af navnet, så eksemplet maner til forsigtighed ved tolkningen af sent overleverede stednavne. Forste led i navnet er gammeldansk with »skov, ved ". For det midterste led er der flere tolkningsmuligheder, idet stadsrettens g kan tænkes at repræsentere enten oprindeligt gh (»blødt « g), gg eller $\mathbf{k}$; oprindeligt $k$ bevares normalt i stadsretten, men svæk kelse til $g(h)$ kan forekomme, når $\mathbf{k}$ som her står $\mathbf{i}$ forholdsvis tryksvag stavelse. I forste tilfælde må midterleddet sammenstilles med oldnordisk stag sstok, stang ", samme ord som det fra dansk, maritimt sprog kendte stag (nu med skriftpåvirket udtaleform, ældre også stav), betegnelse for et tov, som masten støttes med. Hvis leddet har gammeldansk gg, må det være identisk med ældre nydansk stag "spids, brod «, samme ord som det moderne stak »vedhæng pả kornaks " og som gammeldansk stag(g) shundestejle", hvis oprindelige betydning netop er »spids «. Forudsættes endelig oprindeligt k, må det midterste led identificeres med ordet stage, gammeldansk staki. Det er vanskeligt at træffe et valg mellem disse formelle muligheder, idet både betydninger som »stav «, "stage* og "spids» synes at give god mening. Sproghislorisk har navnel interesse ved, at formen fra den nedertyske stadsret viser, at dialektens overgang fra gammeldansk th til $j$, som vi har kunnet konstatere $i$ flere af de foregâende navne, allerede er indtrâdt $i$ slutningen af det 15 . årh.

Af de sproghistoriske oplysninger, der kan hentes gennem marknavnestoffet, er de mest interessante dem, der fremgår af formerne af navnet Morbæk og - indirekte - af Ryde: Rødegade, Rødeport, at dialekten har haft diftongering af langt o og $ø$. Den første af disse diftongeringer kan konstateres allerede $i$ stadsretten (f. eks. i ordet gwoz "gods"), medens diftongeringen af langt $ø$ er af yngre datum. Dialektgeografisk betyder diftongeringerne, at den gamle, danske dialekt i Flensborg har tilhørt det sydslesvigske (angelske), ikke det nordslesvigske dialektområde.

Flensborg bymark rummer også en lang række navne, der giver os oplysninger om byens ældre topografi eller om svundne tiders kulturforhold. Kun et enkelt af disse navne skal fremdrages her: Runtzefall, navn på en dam i Nikolai sogn (jordeb. 1594 Rontze- 
fahl, måske lidt senere tilføjelse $\mathrm{i}$ jordebogen); tilføjelse 1613 i samme jordeb. Dick Runtzefall; kort 1768 runtzefall. Navnet gár i sidste instans tilbage til den middelalderlige Rolandsdigtning. Det er navnet Roncevaux (spansk Roncevalles), i den norske Karlamagnussaga Runzival, der ved opkaldelse har bredt sig til Norden. " I Danmark findes det foruden i Flensborg vistnok i gårdnavnet Rønsvold i Åbenrå. I et glimt viser navnet os, at europæisk middelalderdigtning også var kendt i Sønderjylland.

Forhåbentlig kan disse små prøver på det flensborgske navnestof tjene til at vise, hvilken rigdom af oplysninger der i Flensborg som andetsteds kan hentes fra de gamle marknavne. Af særlig betydning er de sproglige oplysninger, navnene giver os, når det, som i Flensborg, drejer sig om navne, der repræsenterer en dialekt, der ikke mere lever på stedet.

\section{NOTER}

1. Det fuldstændige materiale bringes $i$ sidste hæfte af Sydslesvigs Stednavne Bd. VII, der formentlig vil udkomme 1966. Da der i dette værk bringes udførlige kildehenvisninger, har jeg ment at kunne henvise til disse og i nogle tilfælde nøjes med her at antyde, hvorfra de ældre navneformer stammer. - Selve tolkningen af de en. kelte navne må derimod i Sydslesvigs Stednavne nødvendigvis blive kortfattet.

2. Ingvor Ingvorsens fortællinger om gammelt sjællandsk bondeliv (= Danmarks Folkeminder nr. 20) p. 99. Om Bæver- i stednavne se også Kulturhist. Leks. II $493 \mathrm{f}$.

3. Kousgård Sørensen, Danske bebyggelsesnavne på -sted p. 71.

4. Ortnamnen i Göteborgs och Bohus län II 155.

5. Kort over de danske folkemål nr. 49.

6. Kort over de danske folkemål nr. 13.

7. Jfr. Sønderjy. Stedn. I p. LI.

8. Kort over de danske folkemål nr. 25.

9. Sønderjy. Stedn. I p. LV.

10. Sønderjy. Stedn. III $82 \mathrm{f}$.

11. Kristian Hald, Vore Stednavne 2. udg. p. 222. 